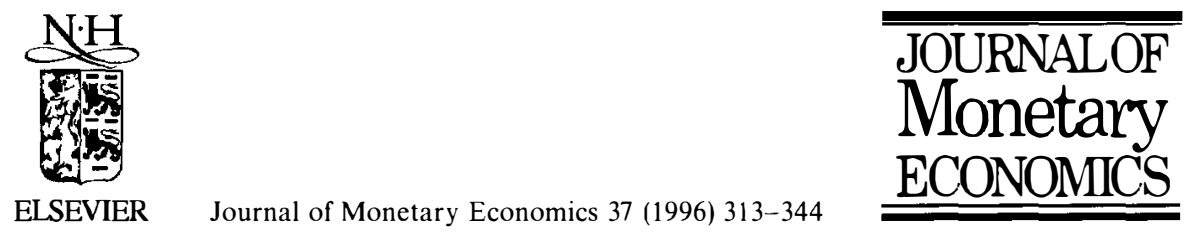

\title{
The composition of public expenditure and economic growth
}

\author{
Shantayanan Devarajan, Vinaya Swaroop*, Heng-fu Zou \\ Policy Research Department, The World Bank, Washington, DC 20433, USA
}

(Received October 1993; final version received February 1996)

\begin{abstract}
Noting that the literature has focused on the link between the level of public expenditure and growth, we derive conditions under which a change in the composition of expenditure leads to a higher steady-state growth rate of the economy. The conditions depend not just on the physical productivity of the different components of public expenditure but also on the initial shares. Using data from 43 developing countries over 20 years we show that an increase in the share of current expenditure has positive and statistically significant growth effects. By contrast, the relationship between the capital component of public expenditure and per-capita growth is negative. Thus, seemingly productive expenditures, when used in excess, could become unproductive. These results imply that developing-country governments have been misallocating public expenditures in favor of capital expenditures at the expense of current expenditures.
\end{abstract}

Key words: Productive and unproductive government expenditures; Economic growth; Developing countries

JEL classification: E62; H50; O40

* Corresponding author.

We are indebted to Min Zhu for exceptionally able research assistance. We received helpful comments from Alberto Alesina, David Aschauer, Robert Barro, Gerry Helleiner, Manny Jimenez, Lant Pritchett, Mike Stevens, Michel Strawczynski, Mike Walton, and seminar participants at Georgetown University, Seoul National University (Seoul, South Korea), the National Institute of Public Finance and Policy (New Delhi, India), the World Bank, and at a conference on 'Africa: From Stabilization to Growth', held in Marstrand, Sweden. The comments from an anonymous referee and the editor were extremely useful in revising the paper. Devarajan and Swaroop acknowledge financial assistance from the World Bank's Research grant RPO \# 676-84. Zou is also affiliated with Wuhan University, China. The views expressed in this paper are not necessarily those of the World Bank. 


\section{Introduction}

Governments in developing countries spend an average of 26 percent of GDP on goods and services, a figure which has risen by eight percentage points over the last fifteen years (World Bank, 1992). The magnitude and growth of this figure has prompted a fair amount of research on the relationship between the size of government and economic growth (for a survey, see Lindauer and Velenchik, 1992). Much less is known about how the composition of public expenditure affects a country's growth rate. Yet, this may be the central question. First, while the size of government is a public-choice issue, its composition is open to policy discussion. Several observers distinguish between 'productive' and 'unproductive' public expenditures, and show how a country can improve its economic performance by changing the mix between the two. Second, after a decade of fiscal adjustment, during which many of the 'white elephants' in government budgets were weeded out, some developing countries are faced with hard choices when undertaking further fiscal restraint. Which component of public expenditure should be cut? Health? Education? Infrastructure? Defense? The answer must depend on, inter alia, the contribution of these components to economic growth.

The purpose of this paper is to shed light on the relationship between the composition of public expenditure and economic growth. Before proceeding, we note that governments undertake expenditures to pursue a variety of goals, only one of which may be an increase in per-capita income. We focus on growth because (i) inasmuch as growth is one of the objectives of a government, it is useful to know the contribution of different components of expenditure to this objective as a means of assessing the cost of pursuing other goals, and (ii) per-capita income is easier to measure than some of the other objectives of government.

Neither economic theory nor empirical evidence provides clear-cut answers to the question of how the composition of public expenditure affects economic growth. The theory develops a rationale for government provision of goods and services based on the failure of markets to provide public goods, internalize externalities, and cover costs when there are significant economies of scale. Furthermore, when there is a failure in one market, government intervention in a related market can be justified. Sound as they are, these theoretical notions do not translate easily into operational rules about which component of public expenditure is to be cut.

On the empirical front, a few researchers have tried linking particular components of government expenditure to private-sector productivity and economic growth but most of these efforts lack a rigorous theoretical framework (Diamond, 1989). The recent revival of interest in the expenditure-composition issue (Aschauer, 1989; Morrison and Schwartz, 1991; Holtz-Eakin, 1991) has been based on theoretical models but the focus has been on the productivity of public expenditures in the United States. 
In this paper, we develop in Section 2 an analytical framework which links the composition of public expenditure with economic growth. In Section 3 we attempt to determine which components of public expenditure - current or capital on the one hand, and health, education, transport and communications, or defense on the other - have been shown to be productive in developing countries. Our major finding is that developing-country governments have been misallocating public expenditures in favor of capital expenditures at the expense of current expenditures. In Section 4 we provide an interpretation of our results. Section 5 presents our concluding remarks.

\section{The model}

Since the 1960's, researchers have been looking at the relationship between fiscal policy and the economy's growth rate. The seminal contribution was by Arrow and Kurz (1970), who developed a model where consumers derive utility from private consumption as well as the public capital stock. In addition, private production benefits from the services of this capital stock. Arrow and Kurz assumed (implicitly) that all government investment was productive. Furthermore, their model was in the neoclassical tradition where public spending only affected the economy's transitional growth rate; the steady-state growth rate remained unaltered.

The recent explosion of work on endogenous growth has generated a number of models linking public spending with the economy's long-term growth rate. A particularly simple version is Barro's (1990), which takes government expenditure to be complementary with private production. Like Arrow and Kurz, Barro assumes that all government spending is productive in this sense.

Meanwhile, the empirical literature on the same topic has highlighted the distinction between productive and unproductive government spending (e.g., Landau, 1983; Aschauer, 1989; Barro, 1990, 1991). A major finding of these studies is that output growth is negatively correlated with the share of government consumption in GDP. Aschauer and Barro also find a positive relationship between public investment and output growth.

We combine the above empirical observation with the earlier theoretical framework by postulating a model in which there are two types of government expenditure, productive and unproductive. The model expresses the difference between productive and unproductive expenditures by how a shift in the mix between the two alters the economy's long-term growth rate. We assume the aggregate production function has three arguments: ${ }^{1}$ private capital stock, $k$,

\footnotetext{
${ }^{1}$ As is typical of these models, we leave out labor as a separate argument in the production function. If the economy in question has surplus labor, then labor is not a binding constraint and can be left out of the production function. Alternatively, we can consider the capital factor, $k$, to reflect human as well as physical capital.
} 
and two types of government spending, $g_{1}$ and $g_{2}$. After developing the model, we will define precisely what it means for, say, $g_{1}$ to be productive and $g_{2}$ to be unproductive. If the functional form is CES (constant elasticity of substitution), then the relationship can be expressed as

$$
y=f\left(k, g_{1}, g_{2}\right)=\left[\alpha k^{-\zeta}+\beta g_{1}^{-\zeta}+\gamma g_{2}^{-\zeta}\right]^{-1 / \zeta},
$$

where

$$
\alpha>0, \quad \beta \geq 0, \quad \gamma \geq 0, \quad \alpha+\beta+\gamma=1, \quad \zeta \geq-1 .
$$

Following Barro (1990), we assume that the government finances its expenditure by levying a flat-rate income $\operatorname{tax}^{2} \tau$,

$$
\tau y=g_{1}+g_{2} .
$$

The share, $\phi(0 \leq \phi \leq 1)$, of total government expenditure which goes toward $g_{1}$ is given by

$$
g_{1}=\phi \tau y \quad \text { and } \quad g_{2}=(1-\phi) \tau y .
$$

Taking the government's decisions on $\tau$ and $\phi$ as given, ${ }^{3}$ the representative agent chooses consumption, $c$, and capital, $k$, to maximize his welfare

$$
U=\int_{0}^{\infty} u(c) \mathrm{e}^{-p t} \mathrm{~d} t
$$

subject to

$$
\dot{k}=(1-\tau) y-c,
$$

where $\rho$ is the rate of time preference.

In order to get analytical solutions, it is useful to specialize the utility function to the isoelastic form:

$$
u(c)=\frac{c^{1-\sigma}-1}{1-\sigma}
$$

\footnotetext{
${ }^{2}$ Our focus is on the composition of expenditure, we abstract from issues of the financing of government expenditures: (a) There is no deficit financing in the model as the government is constrained to run a balanced budget (for a lucid treatment of the deficit financing issue, see Easterly, 1989); and (b) the role of the structure of taxes is not analyzed in examining the effect of total government expenditure on per-capita growth (for a discussion of role of the structure of taxes in explaining growth variations, see Easterly and Rebelo, 1993, who experimented with 13 different tax measures and found only one variable - the marginal income tax rate - to be statistically significant).

${ }^{3}$ While we do not analyze the government's decision problem of choosing expenditure or the tax rate, we are implicitly assuming that the government chooses the tax rate $(\tau)$. Since the government is constrained to run a balanced budget in the model, this effectively means that the level of government expenditure, $g$, is determined by default. Doing a complete analysis of the choice of both $g$ and $\tau$ would be a useful extension to our analysis. See Davoodi, Xie, and Zou (1995) for an attempt.
} 
Substituting (6) into (4) and maximizing subject to (1), (2), (3), and (5) yields the equation for the growth rate of consumption:

$$
\frac{\dot{c}}{c}=\frac{\alpha(1-\tau)\left\{\alpha+(g / k)^{-\zeta}\left[\beta \phi^{-\zeta}+\gamma(1-\phi)^{-\zeta}\right]\right\}^{-(1+\zeta) / \zeta}-\rho}{\sigma} .
$$

Call the steady-state growth rate of consumption $\lambda$, and assume that along the steady-state growth path the tax rate $\tau$ (and hence $g / y$ ) is constant. It follows that $g / k$ is a constant which, by simple manipulation of (1)-(3), is given by

$$
g / k=\left\{\left[\tau^{\zeta}-\beta \phi^{-\zeta}-\gamma(1-\phi)^{-\zeta}\right] / \alpha\right\}^{1 / \zeta} \text {. }
$$

Substituting the value of $g / k$ from (8) into (7) we obtain the steady-state growth rate of consumption as

$$
\lambda=\frac{\alpha(1-\tau)\left\{\alpha \tau^{\zeta} /\left[\tau^{\zeta}-\beta \phi^{-\zeta}-\gamma(1-\phi)^{-\zeta}\right]\right\}^{-(1+\zeta) / \zeta}-\rho}{\sigma} .
$$

From Eq. (9), we can derive a relationship between the steady-state growth rate, $\lambda$, and the share of government expenditure devoted to $g_{1}$ :

$$
\frac{\mathrm{d} i}{\mathrm{~d} \phi}=\frac{\alpha(1-\tau)(1+\zeta)\left[\alpha \tau^{\zeta}\right]^{-(1+\zeta) / \zeta}\left[\beta \phi^{-(1+\zeta)}-\gamma(1-\phi)^{-(1+\zeta)}\right.}{\sigma\left[\tau^{\zeta}-\beta \phi^{-\zeta}-\gamma(1-\phi)^{-\zeta}\right]^{-1 / \zeta}} .
$$

We can now define productive expenditure: that component of public expenditure an increase in whose share will raise the steady-state growth rate of the economy. From Eq. (10), the component $g_{1}$ is productive if $\mathrm{d} \lambda / \mathrm{d} \phi>0$.

What are the implications of this definition for the parameters of the model? Assuming $\lambda$ [given by Eq. (9)] is positive, the right-hand side of (10) will be positive if

$$
(1+\zeta)\left[\beta \phi^{-(1+\zeta)}-\gamma(1-\phi)^{-(1+\zeta)}\right]>0 .
$$

Since $\zeta \geq-1,(11)$ implies that $\mathrm{d} \lambda / \mathrm{d} \phi>0$ if ${ }^{4}$

$$
\frac{\phi}{1-\phi}<\left(\frac{\beta}{\gamma}\right)^{\theta}
$$

where $\theta=1 /(1+\zeta)$ is the elasticity of substitution. Note that the condition (12) - for a shift in the composition to increase the growth rate - depends not just on the productivity $(\beta$ and $\gamma$ ) of the two components but also on the initial shares. Thus, a shift in favor of an 'objectively' more productive type of expenditure (e.g., $\boldsymbol{\beta}>\gamma)$ may not raise the growth rate if its initial share $(\phi)$ is 'too high'.

\footnotetext{
${ }^{4}$ When $\zeta=-1$, the production technology is linear, i.e., $y=\alpha k+\beta g_{1}+\gamma g_{2}$, and the growth rate of consumption is $\lambda=[(1-\tau) \alpha-\rho] / \sigma$. In such a case, the composition of government expenditure plays no role in enhancing the rate of economic growth. This is intuitive, since if $\zeta=-1$, the two components of government expenditure are perfect substitutes.
} 
To see the intuition behind this condition, consider the special case of Cobb-Douglas technology, for which $\zeta=0$ and $\theta=1$. Then condition (12) becomes

$$
\frac{\phi}{1-\bar{\phi}}<\frac{\beta}{\gamma} \text {. }
$$

According to this condition, if the relative share of public expenditure devoted to the two goods $g_{1}$ and $g_{2}$ is below their relative output elasticities ( $\beta$ and $\gamma$ are the output elasticities of $g_{1}$ and $g_{2}$, respectively), then a shift in the mix towards $9_{1}$ will increase the economy's long-run growth rate. ${ }^{5}$ Both elasticities may be positive (i.e., both components of government expenditure are complementary with private production), yet if the above condition holds, transferring resources from $g_{2}$ to $g_{1}$ will raise the steady-state growth rate. Further, $\beta>\gamma$ is not sufficient to guarantee that a shift in favor of $g_{1}$ will increase the growth rate; it must be the case that the relative budget shares are below the relative output elasticities.

Now consider the more general case of a CES technology, where $\theta \neq 1$. Assume $\beta>\gamma$ and define $\phi^{*}$ as the critical value above which an increase in the share of expenditure going to $g_{1}$ will not increase the growth rate. That is,

$$
\frac{\phi^{*}}{1-\phi^{*}}=\left(\frac{\beta}{\gamma}\right)^{\theta}
$$

How will the critical value of $\phi^{*}$ change as $\theta$ increases? Simple manipulation reveals that

$$
\frac{\mathrm{d} \phi^{*}}{\mathrm{~d} \theta}=\left(1-\phi^{*}\right)\left(\frac{\beta}{\gamma}\right)^{\bullet} \ln \left(\frac{\beta}{\gamma}\right),
$$

so that $\mathrm{d} \phi^{*} / \mathrm{d} \theta>0$ since $\beta>\gamma$. As the two types of government expenditure become more and more substitutable, $\phi^{*}$ increases. The intuition is that the more substitutable are the two types of expenditure, the more likely it will be that an increase in the share going to the one with the higher coefficient will increase the growth rate. Conversely, when the substitution elasticity is low, increasing the amount going to $g_{1}$ may not increase the growth rate even if the

\footnotetext{
${ }^{5}$ As pointed out by an anonymous referee, $\phi$, the budgetary share, cannot be equal to either 0 or 1 in the Cobb-Douglas specification because one of the $g$ 's then is zero and so is output. Even the case where $\phi$ is close to 0 or 1 is problematic because output then is arbitrarily small. While this is a restrictive assumption (especially when there are more than two public goods) in the sense that there is no reason to believe that societies cannot set components of government expenditure at any proportions (including zero) they like, the Cobb-Douglas case simplifies the algebra and provides valuable insights into the model. Furthermore, as shown above, the model results hold for the more general CES technology where $0 \leq \phi \leq 1$.
} 
initial share is quite small. In the limiting case, when $\theta=0$, the production function is of the Leontief form and increasing $g_{1}$ 's share over a certain amount will have no effect on the long-run growth rate.

Note that the increase in the growth rate achieved by shifting towards productive expenditure can be accomplished with no change in total government expenditure. In fact, the effect of an increase in the latter on the growth rate is ambiguous. To see this, consider the response of $\lambda$ to an increase in $\tau$ (since $\tau=g / y$, this is equivalent to an increase in the share of government expenditure in GDP). Some tedious manipulation reveals that

$$
\frac{\mathrm{d} \lambda}{\mathrm{d} \tau} \geq(<) 0 \text { if } \frac{\tau^{\zeta+1}}{B}+\tau \zeta \leq(>) 1+\zeta
$$

where

$$
B=\beta \phi^{-\zeta}+\gamma(1-\phi)^{-\zeta} .
$$

Clearly, the relationship between $\tau$ and $\lambda$ is ambiguous and can change sign depending upon the relationship between $\tau$ and $B$, where the latter can be thought of as a proxy for the total productivityof government expenditure. Some further intuition can be derived by considering the Cobb-Douglas technology, in which the above condition reduces to

$$
\frac{\mathrm{d} \lambda}{\mathrm{d} \tau}>0 \text { when } \tau<\beta+\gamma,
$$

and conversely if $\tau>\beta+\gamma$. This is intuitive given our balanced-budget assumption: an increase in total government spending, since it has to be financed by taxes, will raise the steady-state growth rate only if the productivity of that government spending $(\beta+\gamma)$ exceeds the taxes required to pay for it.

The model can be extended in several ways. We now consider three. First, the number of components of government expenditure can be increased from just two. This extension only makes the algebra more cumbersome without improving our knowledge of the growth process. If there are $N$ types of government expenditure, each with its own exponent, $\beta_{i}$, in the production function, and share $\phi_{i}$ in the budget, then the effect on growth of increasing the share of government expenditure going to the ith component depends on which component's share is being reduced. If the increase in $i$ 's share comes from a component $j$ such that

$$
\frac{\beta_{i}^{\theta}}{\phi_{i}}>\frac{\beta_{j}^{\theta}}{\phi_{j}},
$$

then the shift in expenditure composition will increase the steady-state growth rate of the economy. Alternatively, if the above inequality were reversed, then a shift from $j$ to $i$ would lower the long-run growth rate.

Second, not all components of government expenditure affect the production function; some - such as transfers to households - are intended to affect 
consumer welfare. In our model, this can be incorporated by including these components in the consumer's utility function, and allowing their coefficient in the production function to be zero. The rest of the analysis follows as before.

Finally, in this model, we take the government's decisions as given, rather than deriving them from some optimizing framework. Doing the latter requires specifying the government's objective function and the result will depend on this function. While we do not attempt such an exercise in this paper, our results - especially those in the next section - suggest that this may be a fruitful extension. See Davoodi, Xie, and Zou (1995) and Zhang and Zou (1996) for some preliminary results.

Despite its simplicity, the model described above yields an important insight into what makes particular components of government expenditure productive. In particular, it shows that the answer does not depend on the sign of the exponent in the production function; rather, it is a relationship between the coefficient (output elasticity in the Cobb-Douglas case) and the actual share in the budget which determines whether or not a component is productive. However, the formal framework begs the question of which government expenditures are productive and which are not. In the next section, we attempt to answer this question by examining empirically how the growth performance of developing countries over time was affected by the composition of their public expenditures. We ask the data to tell us which components of expenditure are productive.

\section{Empirical analysis}

Our empirical analysis focuses on the link between various components of government expenditure and economic growth in developing countries. Aschauer and Greenwood (1985), Barro (1990), and others emphasize the distinction between public goods and services that enter into the household's utility function and those that complement private sector production. The former, which they argue would include much of government consumption, are likely to have negative growth effects. While it provides utility to households, government consumption lowers economic growth because the higher taxes needed to finance the consumption expenditure reduce returns on investments and the incentive to invest. This is confirmed by Grier and Tullock (1987). Using pooled cross-section/time-series data (115 countries including 24 OECD countries in the post-World War II period), they find a significantly negative relationship between the growth rate of real GDP and government consumption's share of GDP. By contrast, government investment expenditure, such as the provision of infrastructure services, is thought to provide the enabling environment for growth. Aschauer (1989) finds that 'core infrastructure' - streets, highways, airports, mass transit, and other public capital - has the most explanatory power for private-sector productivity in the United States over the period 
1949-85. Based on a set of cross-country regressions, Easterly and Rebelo (1993) find that public investment in transport and communications in developing countries leads to higher economic growth. For other categories of public spending, there appears to be some disagreement over whether they constitute 'productive' expenditure. While Kormendi and Meguire (1985), Grier and Tullock (1987), and Summers and Heston (1988) classify defense and education as government consumption and hence unproductive, Barro (1991) models them as productive. He considers spending on public education as investing in human capital. Similarly, defense spending helps protect property rights which increases the probability that an investor will receive the marginal product of capital. Based on data on 98 countries, Barro (1991) finds that an increase in resources devoted to nonproductive government consumption is associated with lower per-capita growth.

In our analysis, we refrain from an a priori classification of public expenditures into 'productive' and 'unproductive'. Instead, we allow the data to tell us which components conform to our definition of productive expenditure. Furthermore, since ours is a pooled, cross-section/time-series data set, we are able to capture some of the lags involved in translating productive public expenditures into economic growth. Our study is also unique inasmuch as it focuses exclusively on developing countries. Most of the other studies use a mixed sample of developed and developing countries, or examine developed countries only. As we will show, the results change dramatically when the sample is restricted to developing countries.

\subsection{Data and choice of variables}

The empirical analysis uses annual data on 43 countries (see Appendix B for the list of countries) from 1970 through 1990 to examine the link between components of government expenditure and economic growth. The pooled data include total central government expenditures (including current and capital), expenditures for defense, education, health, and transport and communication. ${ }^{6}$ The latter expenditure variable is used as a proxy for expenditure in economic infrastructure.

The model in Section 2 developed links between the shares of government expenditure and the long-term growth rate of the economy. In the empirical analysis, we test whether the share allocated to different components of government expenditure is associated with higher growth. Thus, our key explanatory variable is the share of each component in total government expenditure. To control for level effects, we also include the share of government expenditure in

\footnotetext{
${ }^{6}$ As a check on our results, we repeat our analysis for the subsample of countries for which there are data on consolidated government expenditures (see below).
} 
GDP. This also allows us to control for the effects of financing government expenditure (which is a function of the level) on growth. Given that the pattern of economic growth has been uneven across the continents, we include continent dummies to control for the continent-specific effect. In addition, we attempt to control for two other factors which determine a country's growth rate but are not necessarily linked to the composition of public expenditure: external shocks and other domestic policies. The latter is measured by the premium on the official rate in the black market for foreign exchange. Finally, the dependent variable is the five-year forward moving average of per-capita real GDP growth. ${ }^{7}$ The forward lag is chosen to reflect the fact that public expenditures often take time before their effects on output growth can be registered. We use a five-year average to eliminate short-term fluctuations induced by shifts in public expenditure, and by choosing a moving average we are able to increase the number of time series observation in our panel data.

The choice of a five-year forward lag structure is aimed at addressing another problem which plagues most analyses of the link between public expenditure and growth: the joint endogeneity of the two variables and the possibility of reverse causality. For instance, if education expenditure is negatively associated with growth, it need not necessarily mean that education expenditure is unproductive; it could mean that slow-growing countries spend more on education in an attempt to grow faster. While this problem exists in principle in our paper as well, we attempt to minimize it by modeling expenditure in period $t$ as affecting growth from period $t+1$ through $t+5$. Thus, for the reverse causality argument to hold in our model, governments would have to anticipate the decline in growth rates up to five years into the future and accelerate education spending today. ${ }^{8}$

\subsection{Regression analysis}

The method of ordinary least squares (OLS) is used to estimate the following equation:

$$
\begin{aligned}
& G R P C G D P_{(t+1 . t-5)}^{i}=\sum_{j=1}^{5} \alpha_{j} D_{j}+\alpha_{6}(T E / G D P)_{t}^{t}+x_{7} B M P_{t}^{i} \\
& +\alpha_{8} S H O C K_{i}^{i}+\sum_{k} \alpha_{k}\left(G_{k} / T E\right)_{t}^{i}+\mu_{i}^{i},
\end{aligned}
$$

\footnotetext{
${ }^{7}$ Whether the five-year average is long enough to capture the long-term growth is an issue of contention. In the econometric analysis we tried seven-year and ten-year averages but the results did not change significantly.

${ }^{8}$ If, however, the growth rate has a distributed lag structure, then the joint endogeneity problem may not have been reduced significantly.
} 
where the variables are:

(i) GRPCGDP $P_{(t+1, t+5)}^{i}$ : Five-year forward moving average of per-capita real GDP growth for country $i$.

(ii) $D_{j}$ : Continental dummy variables; $j=1,2,3,4$, and 5 correspond to East Asia, South Asia, sub-Saharan Africa, Latin America, and Europe, Middle East, and North Africa (EMENA), respectively.

(iii) $(T E / G D P)_{i}^{i}$ : Share of total government expenditure in GDP for country $i$ at time $t$.

(iv) $B M P_{i}^{i}$ : Premium in the black market for foreign exchange in country $i$ at time $t$, calculated as $B M E R_{t}^{i}=\left[\left(B M E R_{t}^{i}-O E R_{t}^{i}\right) / O E R_{t}^{i}\right] * 100$, where $B M E R_{t}^{i}=$ black market exchange rate and $O E R_{t}^{i}=$ official exchange rate.

(v) $S H O C K_{t}^{i}$ : The shock variable is a weighted average of changes in the world real interest rate $(R)$ and the export price index $(P X)$ and import price index $(P M)$ for each country. The export and import price indices are index numbers expressed in U.S. dollars converted at the annual average of the country's official exchange rate. The weights are the ratios to GDP of debt, exports $(X)$, and imports $(M)$, respectively. By 'changes' we mean the difference in the average value of these variables between $t-4$ to $t$ and $t+1$ to $t+5$. In symbols it is defined as, $\operatorname{SHOCK}_{t}=$ $\left(R_{t+1, t+5}-R_{t-4, t}\right) *(D E B T / G D P)_{t}-\left(P X_{t+1, t+5}-P X_{t-4 . t}\right) *(X / G D P)_{t}$ $\left.+P M_{t+1, t+5}-P M_{t-4, t}\right) *(M / G D P)_{t}$.

(vi) $(G / T E)_{i}^{i}$. A vector of public expenditure ratios for country $i$ at time $t:{ }^{9}$ Expenditure shares by economic classification: $N c u r / T e=$ ratio of current expenditure (net of interest payments) to total expenditure and $C a p / T e=$ ratio of capital expenditure to total expenditure.

Expenditure shares by functional classification: $D e f / T e=$ ratio of defense expenditure to total expenditure, $\mathrm{Hlth} / \mathrm{T} e=$ ratio of health expenditure to total expenditure [the subcategories of health expenditure include expenditure on hospitals (Hosp), spending on clinics providing mainly outpatient

\footnotetext{
'We use the classification of government expenditure used in the International Monetary Fund's (IMF) Government Financial Statistics. The IMF classification follows two main lines: (1) the economic classification of expenditure which is based on the type or economic characteristics of expenditure, and (2) the functional classification of expenditure which is based on the purpose or function toward which the expenditure is directed. The former is grouped in terms of the type of outlay: (a) Capital Expenditure which covers payments for the purchase or production of new or existing durable goods (i.e., goods with a life of more than one year); and (b) Current or Recurrent Expenditure which in turn includes wages and salaries, other goods and services, interest payments, and subsidies. The latter includes expenditures on (a) economic services (transport and communication, electricity, agriculture, etc.), (b) social services (education, health, etc.), (c) general government services (general public administration, defense, public order and safety, etc.), and (d) other functions. For details, see International Monetary Fund (1986).
} 
services (Inhlth), and other spending on health (Othlth)], $E d / T e=$ ratio of education expenditure to total expenditure [the subcategories of education expenditure include expenditure of spending on schools ( $S c h l)$, spending on universities (Univ), and other spending on education (Othed)], $T a c / T e=$ ratio of transportation and communication expenditure to total expenditure.

(vii) $\mu_{t}^{i}$ : Error term.

By constructing the dependent variable as a five-year forward moving average of per capita real GDP growth we introduce serial correlation in the error terms within a country sample. The standard errors of the OLS estimator are therefore incorrect although estimates are consistent. To correct the standard errors we extend the method of correlation correction outlined by Hansen and Hodrick (1980). ${ }^{10}$

Table 1 contains the estimates of Eq. (13). Eq. (1.1) shows a positive and statistically significant relationship between the five-year forward moving average of per-capita real GDP growth and the ratio of current (net of interest spending) to total expenditure. A unit increase in this ratio increases the per-capita real GDP growth rate by 0.05 percentage points. Clearly, this is an unusual finding. For example, Barro $(1990,1991)$ finds that consumption expenditure (current expenditure less education and defense expenditure) is associated with lower per-capita growth. Furthermore, our result cuts against the grain of policy advice received by developing countries, which prescribes cutting current, rather than capital, expenditures in order to foster long-term growth. In the next subsection, we report on various tests of the robustness of these results, which show that they are not just a statistical anomaly. In the final section, we offer some interpretations of these findings.

The relationship between the capital component of public expenditure and per-capita growth is negative and significant as illustrated in Eq. (1.2). ${ }^{11}$ Once again this belies the standard hypothesis. Public expenditure on capital goods is supposed to add to the country's physical capital (mainly infrastructure - roads, bridges, dams, ports, power plants, etc.). Intuition suggests that the resulting

\footnotetext{
${ }^{10}$ Hansen and Hodrick (1980) introduced an econometric time-series technique to estimate the covariance matrix of the OLS estimator when errors are serially correlated due to the use of overlapping observations. By sampling more finely than the forest interval (i.e., by using overlapping observations) they were able to increase the size of the data in examining the "efficient-markets hypothesis' for foreign exchange markets. We extend their time-series technique to estimate the covariance matrix of the OLS estimator when serial correlation is introduced by using overlapping observations over time in panel data (see Appendix A).

${ }^{11}$ The coefficient is not exactly the negative of current expenditure because the latter is net of interest payments (so that the two shares do not sum to one). When the budgetary share of total current expenditure (i.e., including interest spending) is used, the coefficient is positive, statistically significant, and exactly equal (in absolute value) to the coefficient of current spending.
} 
Table 1

Composition of government expenditure and economic growth, with $t$-statistics in parentheses

Dependent variable $=G R P C G D P$, five-year forward moving average of per capita real GDP growth rate

\begin{tabular}{|c|c|c|c|c|c|c|}
\hline & Eq. (1.1) & Eq. (1.2) & Eq. (1.3) & Eq. (1.4) & Eq. (1.5) & Eq. (1.6) \\
\hline East Asia & $\begin{array}{c}0.06 \\
(0.03)\end{array}$ & $\begin{array}{c}4.58 \\
(3.50)\end{array}$ & $\begin{array}{c}7.29 \\
(3.72)\end{array}$ & $\begin{array}{c}3.70 \\
(0.82)\end{array}$ & $\begin{array}{c}6.66 \\
(2.74)\end{array}$ & $\begin{array}{c}8.21 \\
(1.32)\end{array}$ \\
\hline South Asia & $\begin{array}{c}0.30 \\
(0.14)\end{array}$ & $\begin{array}{c}4.65 \\
(3.20)\end{array}$ & $\begin{array}{c}5.89 \\
(3.85)\end{array}$ & $\begin{array}{c}2.61 \\
(0.51)\end{array}$ & $\begin{array}{c}7.46 \\
(2.75)\end{array}$ & $\begin{array}{c}7.86 \\
(1.21)\end{array}$ \\
\hline Sub-Saharan Africa & $\begin{array}{c}-2.93 \\
(-1.45)\end{array}$ & $\begin{array}{c}1.75 \\
(1.43)\end{array}$ & $\begin{array}{c}3.66 \\
(2.05)\end{array}$ & $\begin{array}{c}0.28 \\
(0.08)\end{array}$ & $\begin{array}{c}2.93 \\
(1.29)\end{array}$ & $\begin{array}{c}4.33 \\
(0.78)\end{array}$ \\
\hline Latin America & $\begin{array}{c}-3.86 \\
(-1.96)\end{array}$ & $\begin{array}{c}0.75 \\
(0.71)\end{array}$ & $\begin{array}{c}2.03 \\
(1.25)\end{array}$ & $\begin{array}{c}6.32 \\
(1.93)\end{array}$ & $\begin{array}{c}4.28 \\
(2.11)\end{array}$ & $\begin{array}{c}7.86 \\
(1.64)\end{array}$ \\
\hline$E M E N A$ & $\begin{array}{c}-0.99 \\
(-0.39)\end{array}$ & $\begin{array}{c}3.38 \\
(1.82)\end{array}$ & $\begin{array}{c}5.27 \\
(2.29)\end{array}$ & $\begin{array}{c}4.22 \\
(1.08)\end{array}$ & $\begin{array}{c}3.91 \\
(1.70)\end{array}$ & $\begin{array}{c}5.78 \\
(1.05)\end{array}$ \\
\hline$T e_{i}^{i G D P}$ & $\begin{array}{c}0.016 \\
(0.43)\end{array}$ & $\begin{array}{c}0.002 \\
(0.06)\end{array}$ & $\begin{array}{l}-0.033 \\
(-0.86)\end{array}$ & & & $\begin{array}{r}-0.039 \\
(-0.48)\end{array}$ \\
\hline Ncur $/ T e$ & $\begin{array}{c}0.046 \\
(1.98)\end{array}$ & & & & & \\
\hline Cap/Te & & $\begin{array}{r}-0.045 \\
(-1.72)\end{array}$ & & & & \\
\hline Def/Te & & & $\begin{array}{c}-0.053 \\
(-1.38)\end{array}$ & $\begin{array}{c}0.093 \\
(0.96)\end{array}$ & $\begin{array}{l}-0.053 \\
(-0.91)\end{array}$ & $\begin{array}{r}-0.006 \\
(-0.05)\end{array}$ \\
\hline Hlth/Te & & & $\begin{array}{l}-0.024 \\
(-0.30)\end{array}$ & & $\begin{array}{c}-0.50 \\
(-2.15)\end{array}$ & \\
\hline$E d / T e$ & & & $\begin{array}{l}-0.021 \\
(-0.36)\end{array}$ & $\begin{array}{c}0.017 \\
(0.16)\end{array}$ & & \\
\hline Tac/Te & & & $\begin{array}{r}-0.145 \\
(-3.16)\end{array}$ & $\begin{array}{c}-0.33 \\
(-5.54)\end{array}$ & $\begin{array}{c}-0.22 \\
(-3.71)\end{array}$ & $\begin{array}{c}-0.30 \\
(-3.41)\end{array}$ \\
\hline SchliTe & & & & & $\begin{array}{c}0.075 \\
(0.65)\end{array}$ & $\begin{array}{c}0.02 \\
(0.07)\end{array}$ \\
\hline Univ;Te & & & & & $\begin{array}{c}0.38 \\
(1.18)\end{array}$ & $\begin{array}{c}0.39 \\
(0.85)\end{array}$ \\
\hline OthediTe & & & & & $\begin{array}{c}0.63 \\
(2.64)\end{array}$ & $\begin{array}{c}-0.56 \\
(-1.02)\end{array}$ \\
\hline HospiTe & & & & $\begin{array}{c}0.29 \\
(0.52)\end{array}$ & & $\begin{array}{c}-0.70 \\
(-2.00)\end{array}$ \\
\hline InhlthiTe & & & & $\begin{array}{c}0.02 \\
(0.03)\end{array}$ & & $\begin{array}{c}0.02 \\
(0.02)\end{array}$ \\
\hline
\end{tabular}


Table 1 (continued)

\begin{tabular}{|c|c|c|c|c|c|c|}
\hline & Eq. (1.1) & Eq. (1.2) & Eq. (1.3) & Eq. (1.4) & Eq. (1.5) & Eq. (1.6) \\
\hline Othlth Te & & & & $\begin{array}{c}1.03 \\
(1.17)\end{array}$ & & $\begin{array}{c}1.05 \\
(1.19)\end{array}$ \\
\hline HlthCap & & & & $\begin{array}{c}-0.16 \\
(-1.89)\end{array}$ & & \\
\hline EdCap & & & & & $\begin{array}{l}-0.025 \\
(-1.45)\end{array}$ & \\
\hline Black & $\begin{array}{r}-0.013 \\
(-2.50)\end{array}$ & $\begin{array}{c}-0.014 \\
(-2.59)\end{array}$ & $\begin{array}{l}-0.010 \\
(-1.96)\end{array}$ & $\begin{array}{c}0.003 \\
(0.09)\end{array}$ & $\begin{array}{l}-0.010 \\
(-1.11)\end{array}$ & $\begin{array}{r}-0.009 \\
(-0.31)\end{array}$ \\
\hline Shock & $\begin{array}{c}-0.05 \\
(-0.75)\end{array}$ & $\begin{array}{r}-0.053 \\
(-0.90)\end{array}$ & $\begin{array}{l}0.008 \\
(0.14)\end{array}$ & $\begin{array}{c}0.005 \\
(0.03)\end{array}$ & $\begin{array}{c}-0.01 \\
(-0.10)\end{array}$ & $\begin{array}{r}-0.051 \\
(-0.27)\end{array}$ \\
\hline Adj. $R$-sq. & 0.33 & 0.30 & 0.37 & 0.81 & 0.53 & 0.79 \\
\hline Obs. & 294 & 305 & 266 & 54 & 121 & 54 \\
\hline DW & 0.56 & 0.55 & 0.66 & 0.92 & 0.84 & 0.83 \\
\hline
\end{tabular}

stock of infrastructure capital would complement private-sector productivity and, hence, have favorable growth effects.

The level effect of total government expenditure ${ }^{12}$ on per-capita growth is positive but statistically insignificant. This is consistent with our model's prediction: to finance a higher level of government spending higher distortionary taxes are needed and the steady-state growth rate will increase only if the productivity of that government spending exceeds the deadweight loss associated with the taxes required to pay for it.

Eq. (1.3) - which includes expenditure shares according to the functional classification - indicates that defense and economic infrastructure are negatively related to per-capita growth. Public spending in health and education also have negative coefficients though they are statistically insignificant. As economic infrastructure expenditures in general have a high proportion of capital expenditures, the finding that it has a negative correlation with per-capita real GDP growth is consistent with the negative correlation found between capital expenditures and per-capita growth in Eq. (1.2). The result is, however, in sharp contrast with the finding of Easterly and Rebelo (1993, p. 431), who report that public investments in transport and communication in developing countries 'seem to be consistently positively correlated with growth with a very high

\footnotetext{
${ }^{12}$ This variable in the regression controls for the level effect of public expenditure as we are primarily interested in examining the link between the composition of public expenditure and economic growth.
} 
coefficient'. ${ }^{13}$ There are at least two reasons why our finding is different from that of Easterly and Rebelo: First, consistent with our theoretical model, our result is on the composition effect of spending on growth; the level effect has been controlled for separately in the regression analysis by the variable $T E / G D P$ (the share of total expenditure in GDP). In other words, a unit increase in the budgetary share of transport and communication spending has to be matched by a unit decrease in some other spending share(s), as the size of total spending remains fixed. On the other hand, Easterly and Rebelo find a positive and statistically significant coefficient on the share of transport and communication spending in GDP - a variable that mixes the level effect of spending with the composition effect. In their analysis, a unit increase in the share of transport and communication spending in GDP does not necessarily mean that other expenditure items - which could enhance the productivity of transport and communication spending - are decreasing. Second, Easterly and Rebelo use a new measure of public investment - one which incorporates public investment by all levels of government as well as investments by public enterprises - in transport and communication in developing countries. While we agree that such a consolidated public investment series is needed to examine the full impact of public expenditures and growth (the expenditure data used in our research are confined to the central government), the authors construct this series from a large collection of World Bank reports on public investment in individual developing countries. Unfortunately, such reports do not present data consistently. For instance, in one country report 'development expenditures' refers exclusively to capital expenditures while in others it contains some current expenditures as well. We are therefore skeptical that meaningful results can be obtained from data constructed in this manner.

In Eq. (1.4), public spending on health care is disaggregated into expenditure on (i) hospital affairs and services [Hosp], (ii) clinics providing mainly outpatient services [Inhlth], and (iii) public health affairs and services (mainly of a preventive nature), applied research, and experimental development related to the health and medical delivery system [Othlth]. Notwithstanding the reduced number of observations with this specification of the health expenditure variable, we find that the coefficient of the share of expenditure on public health affairs and services, etc. [Othlth] is weakly positive for per-capita growth. The other two components of health expenditures have statistically insignificant coefficients. A unit increase in per-capita health expenditure [HlthCap] is however associated with a decline in per-capita growth. Thus, the finding indicates that neither health expenditure per capita nor total public health expenditure as a share of total expenditure is positively related to the per-capita growth rate. It is the share of health expenditure on preventive care and research and development that has some growth effects.

\footnotetext{
${ }^{13}$ This is the only sectoral public spending variable that is statistically significant in their analysis.
} 
In Eq. (1.5), we disaggregate the education variable into expenditure on (i) administration, management, inspection, operation of pre-primary, primary, and secondary education [Schl], (ii) of tertiary education [Univ], and (iii) other education [Othed]. As reported in Eq. (1.5), this last component of education expenditure is positively and significantly related to the per-capita growth rate. This category of spending on education includes subsidiary services to education (transportation, food, lodging, medical, and other such services to students), program units engaged in administering, supporting, or carrying out applied research into teaching methods and objectives, into learning theory and curriculum development, etc. A unit increase in the share of this category of education spending leads to an increase of 0.63 percentage points in per-capita real GDP. The level of education expenditure (measured by per-capita real education expenditure, Edcap) has negative growth effects.

As for the other variables in the regressions, note that the black-market premium is negative and statistically significant in almost all the equations. The sign is what would be expected: the higher the premium, the more distorted the economy, the worse its growth performance. Interestingly, the shock variable is not statistically significant. It is possible that most of the contribution of this variable is being picked up by the regional dummies, which are, for the most part, statistically significant.

\subsection{Alternative specifications and samples}

Given the surprising nature of these results, especially those having to do with current and capital expenditures, we now subject them to a series of tests, to ensure that they are not due to some statistical fluke. The tests are not formal ones. Rather, they are based on our views of possible factors which could be driving these results but were not connected with the productivity of public spending.

\subsubsection{Developed vs. developing countries sample}

Our use of panel data also distinguishes our study from Barro's (1991), which is based on cross-country regressions. It is worth investigating whether this difference, or some other variation between the two approaches, is responsible for the sharp contrast in results. To begin with Barro's study combines both developed and developing countries, whereas our sample is restricted to developing countries only. This appears to be important. Rerunning our regressions with a sample of 21 developed countries, ${ }^{14}$ we find that our conclusions are reversed and the results conform to the standard hypothesis: The coefficient for

\footnotetext{
${ }^{14}$ All OECD countries except Greece, Portugal, and Turkey, which are not part of the 'high-income economies' as defined in World Bank (1994).
} 
Table 2

Composition of government expenditure and economic growth, for developed countries, with tstatistics in parentheses

Dependent variable $=G R P C G D P$, five-year moving average per capita real GDP growth rate

\begin{tabular}{|c|c|c|c|c|c|c|}
\hline & Eq. (2.1) & Eq. (2.2) & Eq. (2.3) & $\mathrm{Eq} .(2.4)$ & $\mathrm{Eq} .(2.5)$ & $\mathrm{Eq} .(2.6)$ \\
\hline Intercept & $\begin{array}{c}8.55 \\
(6.21)\end{array}$ & $\begin{array}{c}1.12 \\
(3.53)\end{array}$ & $\begin{array}{c}1.18 \\
(2.34)\end{array}$ & $\begin{array}{l}1.35 \\
(2.59)\end{array}$ & $\begin{array}{r}0.77 \\
(1.3)\end{array}$ & $\begin{array}{c}0.97 \\
(1.41)\end{array}$ \\
\hline$T e / G D P$ & $\begin{array}{c}0.01 \\
(1.37)\end{array}$ & $\begin{array}{c}0.01 \\
(1.38)\end{array}$ & $\begin{array}{r}0.015 \\
(1.79)\end{array}$ & $\begin{array}{r}0.023 \\
(2.39)\end{array}$ & $\begin{array}{c}0.019 \\
(1.66)\end{array}$ & $\begin{array}{l}0.025 \\
(2.12)\end{array}$ \\
\hline Curite & $\begin{array}{r}-0.074 \\
(-4.72)\end{array}$ & & & & & \\
\hline Cap/Te & & $\begin{array}{c}0.072 \\
(4.57)\end{array}$ & & & & \\
\hline Def:Te & & & $\begin{array}{l}-0.024 \\
(-1.36)\end{array}$ & $\begin{array}{r}-0.024 \\
(-1.24)\end{array}$ & $\begin{array}{l}0.005 \\
(0.26)\end{array}$ & $\begin{array}{r}-0.007 \\
(-0.33)\end{array}$ \\
\hline Hlth/Te & & & $\begin{array}{r}0.019 \\
(1.48)\end{array}$ & & $\begin{array}{c}0.048 \\
(3.12)\end{array}$ & \\
\hline Ed/Te & & & $\begin{array}{l}-0.029 \\
(-1.45)\end{array}$ & $\begin{array}{r}-0.071 \\
(-2.72)\end{array}$ & & \\
\hline Tac/Te & & & $\begin{array}{r}0.089 \\
(3.50)\end{array}$ & $\begin{array}{c}0.09 \\
(3.02)\end{array}$ & $\begin{array}{c}0.002 \\
(0.05)\end{array}$ & $\begin{array}{l}0.036 \\
(1.02)\end{array}$ \\
\hline Schl/Te & & & & & $\begin{array}{c}-0.03 \\
(-1.03)\end{array}$ & $\begin{array}{c}-0.07 \\
(-2.12)\end{array}$ \\
\hline Univ/Te & & & & & $\begin{array}{c}-0.17 \\
(-2.47)\end{array}$ & $\begin{array}{c}-0.14 \\
(-1.88)\end{array}$ \\
\hline OthediTe & & & & & $\begin{array}{c}0.41 \\
(3.52)\end{array}$ & $\begin{array}{c}0.24 \\
(1.93)\end{array}$ \\
\hline HospiTe & & & & $\begin{array}{l}0.036 \\
(2.13)\end{array}$ & & $\begin{array}{c}0.056 \\
(3.11)\end{array}$ \\
\hline InhlthiTe & & & & $\begin{array}{r}-0.081 \\
(-3.34)\end{array}$ & & $\begin{array}{l}-0.035 \\
(-1.20)\end{array}$ \\
\hline Othlth/Te & & & & $\begin{array}{c}0.10 \\
(2.53)\end{array}$ & & $\begin{array}{c}0.11 \\
(2.68)\end{array}$ \\
\hline Ad j. $R$-sq. & 0.06 & 0.06 & 0.06 & 0.18 & 0.14 & 0.21 \\
\hline Obs. & 319 & 319 & 285 & 199 & 211 & 194 \\
\hline DW & 0.46 & 0.45 & 0.52 & 0.58 & 0.49 & 0.59 \\
\hline
\end{tabular}

capital expenditure is positive and statistically significant; and the coefficient for current expenditure is negative and statistically significant.

Table 2 has the estimates of Eq. (13) for the 21 developed countries; the external shock variable and the black market premium were dropped from the 
regression specification. There is no black market for foreign exchange in these countries; and economic growth in developed economies is not affected by the kind of country-specific exogenous shocks captured by our shock variable. To make these results exactly comparable to Barro's, we would have to redefine current expenditure by subtracting total expenditures on education and defense. This is problematic, since current expenditure is part of the economic classification of public expenditure, whereas education and defense fall under the functional category. In other words, to recreate Barro's variables with our data, we would have to subtract apples from oranges. Nevertheless, the reversal of our results for developed countries is interesting in its own right. While the popular view is that developing countries lack infrastructure and other types of public capital, and that developed countries do not, there are several reasons why public capital expenditure could be more productive in developed countries. First, the optimal level of public goods in an economy is a function of the other distortions in the economy (see Hulten, 1994). If distortions in developing countries are such that the desired level of public goods is smaller, then additional expenditure on these public goods may in fact be unproductive. Second, as shown in our theoretical model, an increase in the share going to expenditures which are traditionally considered productive need not raise the growth rate: the initial shares could be such that there is already 'too much' of this kind of expenditure so an increase is counterproductive.

Finally, we investigate whether the difference between using cross-section and panel data is important. If we collapse our panel data set so that we have only one observation per country (taking period averages), our results do change. While the coefficients on current and capital expenditure do not change in signs, they are no longer statistically significant. However, if we lag the period averages (for example, let average public expenditure shares from 1970-1985 affect the average growth rate from 1975-1990), the results begin resembling our earlier ones in Table 1. Thus, allowing for a time lag in the effect of public expenditure on growth - not an unreasonable notion, given the gestation periods of most public projects - has a strong effect on the signs of the coefficients, and could very well be the reason our results differ from Barro's. As noted above, the five-year forward lag structure in our model addresses partially the problem of joint endogeneity. It is possible that the opposite results such as Barro's are due to reverse causality in his model.

\subsubsection{Fixed-effects model}

The regression results reported in Section 3.2 are based on panel data with the implicit assumption that there are no individual cross-sectional effects. It is likely, however, that there are country-specific characteristics which might influence per-capita growth. While such characteristics are generally difficult to measure (e.g., cultural factors), simply running pooled regression may bias the 
coefficient estimates. We apply the fixed-effects method which takes into account country-specific characteristics and models them as fixed effects within the country. In such a case we estimate the following individual-mean corrected regression model:

$$
G R P C G D P_{t+1, t+5}^{i}=\alpha_{i}+\beta_{k} X_{k . t}^{i}+\mu_{t}^{i},
$$

where the variable $X$ consists of all the independent variables of Eq. (13). The computational procedure (see Hsiao, 1992) for estimating the parameters requires transforming the observed variables by subtracting out the appropriate time-series means, and then applying the least-squares method to the transformed data.

Table 3 contains the estimates of the above equation. The issue of interest is: How do the results presented in Table 1 change with the fixed-effects method? Eq. (3.1) in Table 3 shows that the coefficient on the budgetary share of current expenditure (net of interest) continues to be weakly positive and statistically significant. Similarly, the coefficient on capital expenditure's share is negative and statistically significant. The most significant change is the statistical significance of the coefficient on the share of transport and communication. In all but one of four specifications, the negative relationship between transport and communications and per-capita growth is statistically insignificant. One reason for this could be the loss in degrees of freedom in going from continent dummies to the fixed-effects approach. Another interesting feature of this fixed-effects model is that the shock variable, which was previously insignificant, now becomes highly significant, and the black-market premium does the reverse. Evidently, the black-market premium was picking up country-specific characteristics (political instability, etc.). Once these characteristics were explicitly accounted for, the premium loses significance. By contrast, the external shock variable's role appears to have strengthened, since it now captures those determinants of growth not incorporated in the country-specific characteristics.

\subsubsection{Nonlinear specification and other variables}

In this subsection we discuss the regression results based on other specifications of the basic model reported in Eq. (13). In the first instance we attempt a nonlinear specification of the model. Both theory and intuition suggest that expenditure ratios and growth might have a nonlinear relationship. From the model in Section 2 we know that productive expenditures can be positively associated with growth when their shares in the budget are low but this relationship turns negative when the share gets large. The intuition is that as the share keeps rising, decreasing returns to scale set in and, eventually, the relationship between the two variables turns negative.

Table 4 reports the nonlinear regression model. In Eq. (4.1), the growth rate is an increasing function of the share of current expenditure (net of interest 
Table 3

Composition of government expenditure and economic growth, for fixed-effects model, with $t$ statistics in parentheses

Dependent variable $=G R P C G D P$, five-year forward moving average of per capita real GDP growth rate

\begin{tabular}{|c|c|c|c|c|c|c|}
\hline & Eq. (3.1) & Eq. (3.2) & Eq. (3.3) & Eq. (3.4) & Eq. (3.5) & Eq. (3.6) \\
\hline Intercept & $\begin{array}{c}0.041 \\
(0.42)\end{array}$ & $\begin{array}{c}0.1 \\
(1.04)\end{array}$ & $\begin{array}{c}0.048 \\
(0.46)\end{array}$ & $\begin{array}{c}-0.11 \\
(-0.43)\end{array}$ & $\begin{array}{r}-0.023 \\
(-0.14)\end{array}$ & $\begin{array}{c}-0.15 \\
(-0.46)\end{array}$ \\
\hline$T e_{i}^{\prime G D P}$ & $\begin{array}{c}0.002 \\
(0.07)\end{array}$ & $\begin{array}{l}-0.003 \\
(-0.13)\end{array}$ & $\begin{array}{l}-0.015 \\
(-0.47)\end{array}$ & & & $\begin{array}{l}0.035 \\
(0.3)\end{array}$ \\
\hline Ncur/Te & $\begin{array}{l}0.035 \\
(2.7)\end{array}$ & & & & & \\
\hline Cap/Te & & $\begin{array}{l}-0.059 \\
(-3.41)\end{array}$ & & & & \\
\hline DefiTe & & & $\begin{array}{c}0.053 \\
(1.42)\end{array}$ & $\begin{array}{c}-0.13 \\
(-1.23)\end{array}$ & $\begin{array}{c}0.016 \\
(0.27)\end{array}$ & $\begin{array}{c}-0.11 \\
(-0.97)\end{array}$ \\
\hline Hlth/Te & & & $\begin{array}{c}-0.013 \\
(-0.30)\end{array}$ & & $\begin{array}{c}0.14 \\
(0.62)\end{array}$ & \\
\hline Ed/Te & & & $\begin{array}{c}0.006 \\
(0.14)\end{array}$ & $\begin{array}{c}-0.16 \\
(-1.11)\end{array}$ & & \\
\hline TaciTe & & & $\begin{array}{c}-0.037 \\
(-1.14)\end{array}$ & $\begin{array}{c}-0.14 \\
(-1.24)\end{array}$ & $\begin{array}{c}-0.04 \\
(-0.88)\end{array}$ & $\begin{array}{c}-0.13 \\
(-1.00)\end{array}$ \\
\hline Schl/Te & & & & & $\begin{array}{c}0.16 \\
(1.40)\end{array}$ & $\begin{array}{c}-0.29 \\
(-1.37)\end{array}$ \\
\hline Univ/Te & & & & & $\begin{array}{c}0.09 \\
(0.45)\end{array}$ & $\begin{array}{c}0.23 \\
(0.58)\end{array}$ \\
\hline Othed/Te & & & & & $\begin{array}{c}0.16 \\
(0.81)\end{array}$ & $\begin{array}{c}-0.14 \\
(-0.24)\end{array}$ \\
\hline Hosp/Te & & & & $\begin{array}{c}0.75 \\
(0.90)\end{array}$ & & $\begin{array}{c}0.46 \\
(0.48)\end{array}$ \\
\hline InhlthiTe & & & & $\begin{array}{c}0.43 \\
(0.70)\end{array}$ & & $\begin{array}{c}0.21 \\
(0.26)\end{array}$ \\
\hline Othlth/Te & & & & $\begin{array}{c}2.26 \\
(2.48)\end{array}$ & & $\begin{array}{c}2.14 \\
(2.06)\end{array}$ \\
\hline HlthCap & & & & $\begin{array}{c}-0.39 \\
(-3.24)\end{array}$ & & \\
\hline$E d C a p$ & & & & & $\begin{array}{r}-0.091 \\
(-3.88)\end{array}$ & \\
\hline Black & $\begin{array}{l}0.0004 \\
(0.44)\end{array}$ & $\begin{array}{l}0.0005 \\
(0.61)\end{array}$ & $\begin{array}{c}0.001 \\
(1.00)\end{array}$ & $\begin{array}{r}-0.009 \\
(-0.36)\end{array}$ & $\begin{array}{r}0.001 \\
(0.18)\end{array}$ & $\begin{array}{r}-0.009 \\
(-0.33)\end{array}$ \\
\hline
\end{tabular}


Table 3 (continued)

\begin{tabular}{lcccccc}
\hline & Eq. (3.1) & Eq. (3.2) & Eq. (3.3) & Eq. (3.4) & Eq. (3.5) & Eq. (3.6) \\
\hline Shock & -0.096 & -0.095 & -0.12 & 0.017 & -0.096 & -0.065 \\
& $(-3.67)$ & $(-3.67)$ & $(-3.86)$ & $(0.16)$ & $(-1.78)$ & $(-0.50)$ \\
Adj. $R$-sq. & 0.06 & 0.08 & 0.05 & 0.26 & 0.15 & 0.06 \\
Obs. & 294 & 305 & 266 & 54 & 121 & 54 \\
DW & 0.96 & 1.05 & 1.04 & 0.84 & 1.03 & 1.01 \\
\hline
\end{tabular}

Table 4

Composition of government expenditure and economic growth, for nonlinear specification, with $t$-statistics in parentheses

Dependent variable $=G R P C G D P$, five-year forward moving average of per capita real GDP growth rate

\begin{tabular}{|c|c|c|}
\hline & Eq. (4.1) & Eq. (4.2) \\
\hline East Asia & $\begin{array}{c}-6.41 \\
(1.83)\end{array}$ & $\begin{array}{c}2.76 \\
(2.87)\end{array}$ \\
\hline South Asia & $\begin{array}{c}-6.18 \\
(-1.76)\end{array}$ & $\begin{array}{c}2.88 \\
(2.87)\end{array}$ \\
\hline Sub-Saharan Africa & $\begin{array}{c}-9.37 \\
(-2.69)\end{array}$ & $\begin{array}{c}0.04 \\
(0.05)\end{array}$ \\
\hline Latin America & $\begin{array}{l}-10.26 \\
(-2.96)\end{array}$ & $\begin{array}{l}-1.06 \\
(-1.2)\end{array}$ \\
\hline$E M E N A$ & $\begin{array}{c}-7.55 \\
(-2.09)\end{array}$ & $\begin{array}{c}1.35 \\
(1.09)\end{array}$ \\
\hline$T e_{i}^{\prime G D P}$ & $\begin{array}{c}0.02 \\
(0.97)\end{array}$ & $\begin{array}{r}0.008 \\
(0.41)\end{array}$ \\
\hline Ncur/Te & $\begin{array}{c}0.24 \\
(2.39)\end{array}$ & \\
\hline (Ncur/Te)sq. & $\begin{array}{c}-0.001 \\
(-1.95)\end{array}$ & \\
\hline Cap/Te & & $\begin{array}{c}0.11 \\
(1.80)\end{array}$ \\
\hline$(\mathrm{Cap} / \mathrm{Te}) \mathrm{sq}$ & & $\begin{array}{r}-0.003 \\
(-2.62)\end{array}$ \\
\hline Black & $\begin{array}{l}-0.013 \\
(-4.0)\end{array}$ & $\begin{array}{r}-0.014 \\
(-4.58)\end{array}$ \\
\hline Shock & $\begin{array}{l}-0.048 \\
(-1.37)\end{array}$ & $\begin{array}{l}-0.059 \\
(-1.7)\end{array}$ \\
\hline Adj. $R$-sq. & 0.33 & 0.32 \\
\hline Obs. & 294 & 305 \\
\hline DW & 0.57 & 0.59 \\
\hline
\end{tabular}


spending) in the budget and a decreasing function of the square term. While the first variable is strongly significant $(t$-value $=2.39)$, the square term is insignificant at the conventional 5 percent level. There is one clear explanation of this result: Most of the data points are clustered around the positive and upwardsloping part of the functional relationship. Therefore, it is likely that the linear relationship gives a better fit. The nonlinear specification for the capital expenditure ratio is reported in Eq. (4.2). The function attains a maximum when the ratio is around 18 percent. While the coefficient on the square term is statistically significant, the coefficient on the other variable is not. Once again these results corroborate our earlier findings reported in Table 1. In this case most of the data points cluster around the downward sloping negative part of the functional relationship.

As a check on our results we also include each country's per-capita GDP in 1969 as a proxy for the initial level of development for that country. Previous students of the growth process (e.g., Chenery and Syrquin, 1975) have found this variable to be an important factor in determining the relationship between, say, openness and growth. When this variable is included, the results reported in Table 1 remain unchanged. The variable itself has a negative sign and is statistically insignificant. However, the variable becomes significant when we drop the continent dummies although, again there is no change in the other coefficients. $^{15}$

\subsubsection{General vs. central government spending}

Our data set covers the operations of only the central government. Ideally, one would like to examine the impact of total government expenditures that includes the operations of state and local governments as well as expenditures of government-owned or -controlled enterprises, on economic growth. This may be particularly important in the case of health and education expenditures; where in some federal systems, the bulk of these expenditures are carried out by subnational governments. Such comprehensive and consistent expenditure series (across countries and over time) are not available. However, there are a few countries for which consolidated general government expenditures (i.e., operations of central, state, and local governments) are reported in the GFS.

In order to determine whether or not including state and local government expenditure data qualitatively and quantitatively affects our results, we do a few diagnostic tests. Of the 43 countries in our sample, there are nine (see Appendix $\mathrm{B}$ for the list) for which consolidated general government expenditure data are reported in the GFS. We use this sample of nine countries to ascertain whether

\footnotetext{
${ }^{15}$ For space considerations these results are not reported here. They are available from the authors.
} 
Table 5

Sample statistics for central and general government expenditure shares, for nine countries, 1971-90

\begin{tabular}{|c|c|c|c|c|c|c|c|c|c|c|}
\hline & \multicolumn{2}{|c|}{ Observations } & \multicolumn{2}{|l|}{ Mean } & \multicolumn{2}{|c|}{ Std. deviation } & \multicolumn{2}{|c|}{ Maximum } & \multicolumn{2}{|c|}{ Minimum } \\
\hline & $\mathrm{CC}$ & CG & $\mathrm{CC}$ & CG & $\mathrm{CC}$ & CG & $\mathrm{CC}$ & CG & $\mathrm{CC}$ & CG \\
\hline Cur/Te & 184 & 135 & 79.46 & 76.99 & 12.64 & 14.16 & 98.05 & 97.73 & 47.15 & 45.44 \\
\hline Ncur/Te & 184 & 135 & 70.70 & 68.85 & 12.90 & 14.28 & 91.86 & 93.07 & 35.12 & 32.11 \\
\hline Cap/Te & 184 & 135 & 20.55 & 20.97 & 12.62 & 12.09 & 52.85 & 51.95 & 1.95 & 1.95 \\
\hline $\operatorname{Def} / T e$ & 145 & 121 & 11.95 & 8.67 & 5.70 & 5.93 & 26.24 & 20.76 & 1.69 & 0.01 \\
\hline Hlth/Te & 182 & 126 & 6.17 & 6.62 & 3.73 & 3.79 & 19.83 & 19.44 & 1.09 & 2.01 \\
\hline$E d u / T e$ & 182 & 126 & 11.82 & 13.43 & 5.94 & 3.53 & 24.00 & 24.31 & 1.46 & 6.52 \\
\hline Tac/Te & 179 & 125 & 8.63 & 8.85 & 6.40 & 6.02 & 48.27 & 27.99 & 0.90 & 1.96 \\
\hline
\end{tabular}

The nine countries are: Argentina, Chile, Ethiopia, Indonesia, India, Kenya, Malawi, Panama, Zimbabwe.

$\mathrm{CC}=$ consolidated central government and $\mathrm{CG}=$ consolidated general government.

the expenditure ratios used in our analysis are statistically different for general government from central government in these countries.

Table 5 presents the sample statistics for the expenditure ratios. In comparing the statistics for the two different levels of government, a couple of interesting facts emerge: as defense is primarily the responsibility of the central government, the ratio of defense to total expenditure decreases for general government; the share of education expenditure is larger for general government indicating that state and local government allocate a higher budgetary share for education. The expenditure ratios presented in Table 5 also seem to indicate that state and local governments spend more money on capital but less on current expenditure. Based on a paired $t$-test, we find that all expenditure ratios but transport and communication based on general government data are statistically different (significant at the $99 \%$ level) from the ratios based on central government data. ${ }^{16}$

To test whether or not the relationship between the composition of expenditure and economic growth is different when expenditure shares based on general government data are used, we run the same regression model based on each of the two data sets. The regression results are reported in Table 6 .

While the signs and magnitudes of the coefficients are similar for both data sets, the coefficients are statistically insignificant. A paired $t$-test, however, indicates that the difference between the coefficients is statistically insignificant. Hence, the coefficient estimates of the growth equations based on general government expenditure and central government expenditure are statistically the same.

\footnotetext{
${ }^{16}$ For space considerations these results are not reported here. They are available from the authors.
} 
Table 6

Composition of government cxpenditure and economic growth, with $t$-statistics in parenthescs

Dcpendent variable $=$ GRPCGDP, five-year moving average per capita real GDP growth rate

\begin{tabular}{|c|c|c|c|c|c|c|c|c|c|}
\hline & Eq. (C.1) & Eq. (G.1) & $t$-test & Eq. (C.2) & Eq. (G.2) & $t$-test & Eq. (C.3) & Eq. (G.3) & $t$-test \\
\hline East Asia & $\begin{array}{c}4.53 \\
(2.25)\end{array}$ & $\begin{array}{l}4.88 \\
(2.52)\end{array}$ & 0.023 & $\begin{array}{c}1.17 \\
(0.53)\end{array}$ & $\begin{array}{c}2.09 \\
(0.88)\end{array}$ & -0.286 & $\begin{array}{c}-1.62 \\
(-0.54)\end{array}$ & $\begin{array}{c}1.41 \\
(0.68)\end{array}$ & -0.83 \\
\hline South Asia & $\begin{array}{l}4.92 \\
(2.04)\end{array}$ & $\begin{array}{c}5.14 \\
(1.97)\end{array}$ & 0.086 & $\begin{array}{l}2.54 \\
(2.36)\end{array}$ & $\begin{array}{c}2.48 \\
(1.67)\end{array}$ & 0.035 & $\begin{array}{c}1.695 \\
(0.88)\end{array}$ & $\begin{array}{c}0.84 \\
(0.48)\end{array}$ & 0.33 \\
\hline Sub-Saharan Africa & $\begin{array}{c}2.92 \\
(0.98)\end{array}$ & $\begin{array}{c}2.52 \\
(0.75)\end{array}$ & 0.11 & $\begin{array}{c}0.28 \\
(0.16)\end{array}$ & $\begin{array}{l}-0.06 \\
(-0.03)\end{array}$ & 0.132 & $\begin{array}{c}-6.41 \\
(-1.46)\end{array}$ & $\begin{array}{l}-3.60 \\
(-1.37)\end{array}$ & -0.55 \\
\hline Latin America & $\begin{array}{r}4.68 \\
(1.47\end{array}$ & $\begin{array}{c}4.65 \\
(1.35)\end{array}$ & 0.072 & $\begin{array}{c}2.25 \\
(1.18)\end{array}$ & $\begin{array}{c}1.92 \\
(0.97)\end{array}$ & 0.119 & $\begin{array}{c}-2.78 \\
(-0.83)\end{array}$ & $\begin{array}{c}-2.01 \\
(-0.75)\end{array}$ & -0.18 \\
\hline$E M E N A$ & 0 & 0 & 0 & 0 & 0 & 0 & 0 & 0 & 0 \\
\hline$T e / G D P$ & $\begin{array}{c}-0.025 \\
(-0.41)\end{array}$ & $\begin{array}{c}-0.026 \\
(-0.44)\end{array}$ & -0.048 & $\begin{array}{l}-0.023 \\
(-0.39)\end{array}$ & $\begin{array}{c}-0.02 \\
(-0.35)\end{array}$ & -0.036 & $\begin{array}{l}-0.011 \\
(-0.13)\end{array}$ & $\begin{array}{c}-0.012 \\
(-0.164)\end{array}$ & 0.0087 \\
\hline Nucr/Te & $\begin{array}{l}-0.024 \\
(-0.91)\end{array}$ & $\begin{array}{c}-0.027 \\
(-0.98)\end{array}$ & 0.065 & & & & & & \\
\hline
\end{tabular}




\begin{tabular}{|c|c|c|c|c|c|c|c|c|c|}
\hline & & & & $\begin{array}{r}0.043 \\
(1.35)\end{array}$ & $\begin{array}{c}0.033 \\
(0.92)\end{array}$ & 0.215 & & & \\
\hline Def/Te & & & & & & & $\begin{array}{c}0.016 \\
(0.194)\end{array}$ & $\begin{array}{c}-0.086 \\
(-1.11)\end{array}$ & 0.89 \\
\hline $\mathrm{Hlth} / \mathrm{Te}$ & & & & & & & $\begin{array}{c}0.066 \\
(0.336)\end{array}$ & $\begin{array}{c}0.149 \\
(0.91)\end{array}$ & -0.32 \\
\hline$E d / T e$ & & & & & & & $\begin{array}{c}0.223 \\
(1.35)\end{array}$ & $\begin{array}{c}0.152 \\
(1.33)\end{array}$ & 0.35 \\
\hline$T a c / T e$ & & & & & & & $\begin{array}{c}0.175 \\
(2.17)\end{array}$ & $\begin{array}{c}0.062 \\
(1.14)\end{array}$ & 1.15 \\
\hline Black & $\begin{array}{c}-0.014 \\
(-1.45)\end{array}$ & $\begin{array}{c}-0.012 \\
(-0.91)\end{array}$ & 0.127 & $\begin{array}{r}-0.015 \\
(-1.56)\end{array}$ & $\begin{array}{l}-0.015 \\
(-1.19)\end{array}$ & 0.0 & $\begin{array}{c}-0.0079 \\
(-0.441)\end{array}$ & $\begin{array}{l}-0.00008 \\
(-0.005)\end{array}$ & -0.345 \\
\hline Shock & $\begin{array}{c}-0.03 \\
(-0.34)\end{array}$ & $\begin{array}{r}-0.017 \\
(-0.18)\end{array}$ & -0.27 & $\begin{array}{c}-0.046 \\
(-0.54)\end{array}$ & $\begin{array}{l}0.018 \\
(0.2)\end{array}$ & -0.505 & $\begin{array}{c}0.042 \\
(0.46)\end{array}$ & $\begin{array}{c}0.049 \\
(0.57)\end{array}$ & -0.056 \\
\hline Adj. $R$-sq. & 0.44 & 0.47 & & 0.45 & 0.46 & & 0.52 & 0.62 & \\
\hline Obs. & 60 & 57 & & 60 & 57 & & 51 & 46 & \\
\hline DW & 0.96 & 1.00 & & 0.95 & 0.97 & & 1.02 & 1.46 & \\
\hline
\end{tabular}

In the equation numbers $\mathrm{C}$ stands for central and $\mathrm{G}$ for general government, and 't-tcst' indicates the $t$-test for the differences between $\beta_{k c}$ and $\beta_{k g}$ ' 


\section{Interpreting the results}

The empirical implementation of the model yielded what at first glance seem like surprising results. All of the standard candidates for productive expenditure - capital, transport and communication, health, and education - had either a negative or insignificant relationship with economic growth. The only broad category which was associated with higher economic growth was current expenditure.

But these results are not so surprising if we recall the theoretical model. Seemingly productive expenditures may be unproductive if there is an excessive amount of them. Our empirical results show that developing-country governments have been misallocating public expenditures in favor of capital expenditures at the expense of current expenditures, and the developed countries have been doing the reverse. If, as we suspect, these results stand up to further scrutiny, they have important implications for policy. The widespread recommendation to increase public investment's share of the budget in developing countries could be misleading. Several components of current expenditure, such as operations and maintenance, may have higher rates of return than capital expenditure.

This line of inquiry opens up several questions for further research. One is whether public expenditures on capital goods enhance public capital stocks which have been shown to be associated with economic growth (Canning and Fay, 1993; Levine and Renelt, 1992). If not, why not? A second issue is how governments choose the level and composition of expenditure. Some government objective functions would be consistent with our results; for instance, some capital expenditures ('white elephants') could be in the governments objective function. What then do our results say about government behavior in developing countries? These open questions notwithstanding, the basic message arising from this paper is that the traditional view of the link between the composition of public expenditures and economic growth is not borne out by the historical experience of developing countries.

\section{Conclusion}

This paper investigated the relationship between the composition of pubic expenditure and economic growth. Using a simple, analytical model, we derived conditions under which a change in the mix of public spending could lead to a higher steady-state growth rate for the economy. The conditions depended not just on the physical productivity of different components of public spending but also on the shares of government expenditure allocated to them. Based on the model, our empirical results suggest that expenditures which are normally considered productive could become unproductive if there is an excessive 
amount of them. In particular, capital expenditures - often thought to be the mainstay of development - may have been excessive in developing countries, rendering them unproductive at the margin. Because they are squeezed by capital spending, current expenditures are actually productive at the margin. These results confirm that developing-country governments have been misallocating resources, but show that the direction of bias is quite different from the standard view.

\section{Appendix A}

Overlapping observations and serial correlation: Estimation of the covariance matrix of the OLS estimator

The Gauss-Markov assumptions for the method of ordinary least squares estimation are

$$
\begin{array}{ll}
\mathrm{E}\left(\mu_{t}^{i}\right)=0 & \text { for all countries } i, \\
\mathrm{E}\left(\mu_{t}^{i} \mu_{t+h}^{j}\right)=0 & \text { for } h \neq 0, \\
=\sigma^{2} & \text { for } i=j, h=0 .
\end{array}
$$

Proposition. If

$$
Y_{(t+1, t+k)}^{i}=\beta X_{t}^{i}+\mu_{t, k}^{i}
$$

is the regression equation to be estimated by the standard OLS technique where the dependent variable is a $k$-year forward moving average, then under the Gauss-Markov assumptions the error structure satisfies the following:

$$
\begin{aligned}
\mathrm{E}\left(\mu_{t, k}^{i} \mu_{t+h, k}^{j}\right) & =0 \text { for } i \neq j, \\
& =0 \text { for } h \geq k, \\
& \neq 0 \text { for } i=j, \quad h<k .
\end{aligned}
$$

Proof. We will prove the proposition by contradiction. Suppose that all the standard Gauss-Markov assumptions are satisfied. Therefore:

$$
\mathrm{E}\left(\mu_{t, k}^{i} \mu_{t+h, k}^{j}\right)=0, \quad i=j, \quad h<k .
$$

The above assumption implies

$$
\mathrm{E}\left[\left\{Y_{(\mathrm{t}+1, t+k)}^{i}-\beta X_{t}^{i}\right\}\left\{Y_{(\mathrm{t}+h+1, t+h+k)}^{i}-\beta X_{t+h}^{i}\right\}\right]=0, \quad h<k .
$$

Let

$$
Y_{(t+1, t+k)}=Y_{t, k} \quad \text { and } \quad Y_{(t+h+1, t+h+k)}=Y_{t+h, k}
$$


Then

$$
\begin{array}{ll}
\mathrm{E}\left(Y_{t, k}^{i} Y_{t+h, k}^{i}\right)-\beta X_{t}^{i} \mathrm{E}\left(Y_{t+h, k}^{i}\right)-\beta X_{t+h}^{i} \mathrm{E}\left(Y_{t, k}^{i}\right) & \\
\quad+\beta X_{t}^{i} \beta X_{t+h}^{i}=0, & h<k
\end{array}
$$

or

$$
\begin{array}{ll}
\mathrm{E}\left(Y_{t, k}^{i} Y_{t+h, k}^{i}\right)-\mathrm{E}\left(Y_{t, k}^{i}\right) \mathrm{E}\left(Y_{t+h, k}^{i}\right)-\mathrm{E}\left(Y_{t+h, k}^{i}\right) \mathrm{E}\left(Y_{t, k}^{i}\right) & \\
\quad+\mathrm{E}\left(Y_{t k}^{i}\right) \mathrm{E}\left(Y_{t+h, k}^{i}\right)=0 & h<k .
\end{array}
$$

Further, this can be written as

$$
\mathrm{E}\left(Y_{t, k}^{i} Y_{t+h, k}^{i}\right)=\mathrm{E}\left(Y_{t, k}^{i}\right) \mathrm{E}\left(Y_{t+h, k}^{i}\right), \quad h<k .
$$

But this means that $Y_{t, k}^{i}$ and $Y_{t+h, k}^{i}$ for $h<k$ are uncorrelated. This is a contradiction because the dependent variable being a $k$-year forward moving average implies $Y_{i, k}^{i}$ and $Y_{t+h, k}^{i}$ are correlated for $h<k$. Hence, it must be the case that

$$
\mathrm{E}\left(\mu_{i, k}^{i} \mu_{i+h, k}^{j}\right) \neq 0, \quad i=j, \quad h<k . \quad \text { Q.E.D. }
$$

We have shown that, by using overlapping observations in panel data, serial correlation over time is introduced in the error structure in the simple OLS regression analysis. The errors are correlated as long as the sampling interval is less than the moving average lag. Given this correlation, the OLS procedure yields consistent estimates but the standard errors needed to apply tests of significance are incorrect.

To correct the standard errors of the least-squares estimators, we use a methodology first proposed by Hansen and Hodrick (1980) in examining restrictions on a $k$-step ahead forecasting equation. We extend the applicability of their technique from time-series to panel data (pooled cross-section/time-series data).

Hansen and Hodrick (1980) note that in testing hypotheses concerning the parameters of a $k$-step ahead linear forecasting equation

$$
\mathrm{E}\left(y_{t-k} / \phi_{t}\right)=x_{t} \beta
$$

one way to ensure that the errors are serially uncorrelated is to define the sampling interval to be equal to the forecast interval. In the context of tests of exchange market efficiency, however, this procedure of using nonoverlapping observations to avoid serial correlation, does not make use of all available data. In testing the efficient-markets hypothesis for foreign exchange markets, Hansen and Hodrick use data sampled more finely than the forecast interval. They propose a modified OLS technique which allows the estimation of the covariance matrix of the OLS estimator.

Hansen and Hodrick (1980) show that $\sqrt{T}\left(\hat{\beta}_{T}-\beta\right)$ converges in distribution to a normally distributed random vector with mean zero and covariance matrix 
$\Theta$, where $T$ is the sample size, $\hat{\beta}_{T}$ is the OLS estimator,

$$
\Theta=R_{x}(0)^{-1} \Xi R_{x}(0)^{-1} \text { and } \Xi=\sum_{j=-k+1}^{k-1} R_{u}(j) R_{x}(j),
$$

and

$$
R_{x}(j)=\mathrm{E}\left(x_{t}^{\prime} x_{t+j}\right) \text { and } R_{u}(j)=\mathrm{E}\left(u_{t, k} u_{t+j, k}\right) .
$$

Further, they show that

$$
\hat{R}_{x}^{T}(j)=\frac{1}{T} \sum_{t=j+1}^{T} x_{t}^{\prime} x_{t-j} \quad \text { and } \quad \hat{R}_{u}^{T}(j)=\frac{1}{T} \sum_{t=j+1}^{T} \hat{u}_{t, k}^{T} \hat{u}_{t-j, k}^{T}
$$

are consistent estimators of $R_{x}(j)$ and $R_{u}(j)$, respectively. Thus, by estimating the covariance matrix they compute asymptotically justified confidence regions of the OLS estimator.

Using panel data we extend their analysis by noting that for country $i=1, \ldots, N$ with observations $t=1, \ldots, T$

$$
\mathrm{E}\left(y_{t+k}^{i}\right)=x_{t}^{i} \boldsymbol{\beta} .
$$

Thus, along the lines of the Hansen-Hodrick methodology

$$
\hat{\Theta}_{N \times T}=\left(X_{N * T}^{\prime} X_{N * T}\right)^{-1} X_{N * T}^{\prime} \hat{\Omega}_{N \times T} X_{N * T}\left(X_{N * T}^{\prime} X_{N * T}\right)^{-1}
$$

is a consistent estimator of the covariance matrix of the OLS estimator, $\hat{\beta}_{N * T}$; $X_{N * T}$ is a column vector formed by stacking the $N * T$ observations on $x_{t}$; and $\hat{\Omega}$ is a symmetric $N * T \times N * T$ matrix whose lower triangular representation is

$$
\begin{array}{rlrl}
a_{t+n, t} & =\hat{R}_{\mu}(0), & & n=0, \quad t=1, \ldots, N * T, \\
& =\hat{R}_{\mu}(n), & & n=1, \ldots, k-1, \quad t \neq \lambda T-j+1, \\
& & \text { where } \lambda=1, \ldots, N-1, j=1, \ldots, n, \\
& =0, & & \text { otherwise, }
\end{array}
$$

where

$$
\hat{R}_{\mu}(j)=\frac{1}{N * T} \sum_{i=1}^{N} \sum_{t=j+1}^{T} \hat{\mu}_{t, k}^{i} \hat{\mu}_{t-j, k}^{i} .
$$

In extending the applicability of the Hansen-Hodrick technique to panel data one significant change is introduced in the structure of the covariance matrix. This is due to the following assumption:

$$
\mathrm{E}\left(\mu_{t, k}^{i} \mu_{t+h, k}^{j}\right)=0, \quad i \neq j, \quad \text { for any } h \text { and } k .
$$

The implication is that by using overlapping observations for a country in panel data, serial correlation is introduced over time but not across country. 


\section{Appendix B}

\section{Data}

Annual data on 43 developing countries (see the list below) from 1970 through 1990 were used for the empirical analysis. Several sources were used (see below the section on sources) to assemble the data base. At this point, we are still in the process of collecting additional data.

The primary source for data on government expenditure is Government Finance Statistics (GFS), an annual publication of the International Monetary Fund. Ideally, we would like to have consolidated general government (including the expenditures of public-sector enterprises) expenditure data to examine the full impact of public expenditures on economic growth. Unfortunately, such data do not exist in sufficient quantity for the majority of developing countries. GFS coverage is comprehensive for central government accounts but is quite restricted for the accounts of general government. For this reason, the main empirical results presented in data used in this paper are based on central government expenditures. The operations of state and local governments as well as expenditures of government owned or controlled public-sector enterprises are not accounted for. Regression results based on consolidated general government (includes central, provincial and municipal) expenditures are presented in Table 6. Within the main sample of 43 countries, expenditure data on 34 countries are on consolidated central government (includes central government account, social security, and extra budgetary account), and on the remaining nine countries, it only accounts for budgetary central government.

\section{B.1. Data sources}

(i) Government Finance Statistics (GFS), International Finance Statistics (IFS), and National Accounts (BESD - World Bank Economic and Social Database) - all from the International Monetary Fund.

(ii) International Currency Analysis, Inc., World Currency Yearbook, New York.

(iii) IECNA in BESD; World Development Report (WDR), 1991; World Debt Tables (WDT) - all from the World Bank.

\section{B.2. Countries}

Country groups: Regional classification

5 East Asia countries, 3 South Asia countries, 18 sub-Saharan Africa countries, 13 Latin American and Caribbean countries, and 4 Europe, Middle East, and North Africa (EMENA) countries. 


\section{Country groups: Income levels}

19 Low-income countries, 22 middle-income (lower-level) countries, and 2 middle-income (upper-level) countries.

\section{Country list}

Argentina*, Bolivia, Brazil, Burkina Faso, Cameroon, Chile*, Colombia, Costa Rica, Egypt, Arab Republic of, El Salvador, Ethiopia*, Guatemala, India*, Indonesia*, Kenya*, Korea, Republic of Liberia, Malawi*, Malaysia, Mali, Mauritania, Mauritius, Mexico, Morocco, Nicaragua, Nigeria, Pakistan, Panama*, Peru, Philippines, Rwanda, Senegal, Sri Lanka, Sudan, Syrian Arab Republic, Tanzania, Thailand, Togo, Turkey, Venezuela, Zaire, Zambia, and Zimbabwe* (the asterisks indicate countries for which general government expenditure is also available in the GFS).

\section{References}

Arrow, K.J. and M. Kurz, 1970, Public investment, the rate of return and optimal fiscal policy (Johns Hopkins University, Baltimore, MD).

Aschauer, D., 1989, Is government spending productive?, Journal of Monetary Economics 23, 177-200.

Aschauer, D. and J. Greenwood, 1985, Macroeconomic effects of fiscal policy, Carnegie-Rochester Conference Series on Public Policy 23, 91-138.

Barro, R.J., 1990, Government spending in a simple model of endogenous growth, Journal of Political Economy 98, S103-S125.

Barro, R.J., 1991, Economic growth in a cross section of countries, Quarterly Journal of Economics $106,407-444$.

Canning, D. and M. Fay, 1993, The effect of transportation networks on economic growth, Discussion paper (Department of Economics, Columbia University, New York, NY).

Chenery, H.B. and M. Syrquin, 1975, Patterns of development: 1950-1970(Oxford University Press, London).

Davoodi, H., D. Xie, and H. Zou, 1995, Fiscal decentralization and economic growth in the United States, Mimeo. (The World Bank, Washington, DC).

Diamond, J., 1989, Government expenditure and economic growth: An empirical investigation. Working paper no. 89/45 (International Monetary Fund, Washington, DC).

Easterly, W., 1989, Policy distortions, size of government and growth, NBER working paper no. 3214, Dec.

Easterly, W. and S. Rebelo, 1993, Fiscal policy and economic growth: An empirical investigation, Journal of Monetary Economics 32, 417-458.

Grier, K. and G. Tullock, 1989, An empirical analysis of cross-national economic growth, 1951-1980, Journal of Monetary Economics 24, 259-276.

Hansen, L.P. and R.J. Hodrick, 1980, Forward exchange rates as optimal predictors of future spot rates: An econometric analysis, Journal of Political Economy 88, 830-853.

Holtz-Eakin, D., 1991, Public-sector capital and the productivity puzzle, Mimeo. (Syracuse University, Syracuse, NY).

Hsiao, C., 1992, Analysis of panel data, Econometric Society monograph (Cambridge University Press, Cambridge).

Hulten, C., 1994, Optimal growth with infrastructure capital: Theory and implications for empirical modeling, Mimeo. (University of Maryland, Baltimore, MD). 
International Monetary Fund, 1986, A manual on government finance statistics (International Monetary Fund, Washington, DC).

Kaufman, D., 1991, The forgotten rationale for policy reform: The productivity of Bank and IFC investment projects, Mimeo. (The World Bank, Washington, DC).

Kormendi, R.C. and P.G. Meguire, 1985, Macroeconomic determinants of growth: Cross-country evidence, Journal of Monetary Economics 16, 141-164.

Landau, D., 1983, Government expenditure and economic growth: A cross-country study, Southern Economic Journal 49, 783-792.

Levine, R. and D. Renelt, 1992, A sensitivity analysis of cross-country growth regressions, American Economic Review 82, 942-963.

Lindauer, D.L. and A.D. Velenchik, 1992, Government spending in developing countries: Trends, causes and determinants, World Bank Research Observer 7, 59-78.

Morrison, C. and A.E. Schwartz, 1991, State infrastructure and productive performance, Mimeo. (Tufts University, Medford, MA).

Summers, R. and A. Heston, 1988, A new set of international comparisons of real product and price levels: Estimates for 130 countries, Review of Income and Wealth 34, 1-25.

World Bank, 1992, World development report (The World Bank, Washington, DC).

World Bank, 1994, World development report (The World Bank, Washington, DC).

Zhang, T. and H. Zou, 1996, The growth impacts of intersectoral and intergovernmental allocation of public expenditures, Mimeo. (The World Bank, Washington, DC). 